Original Research Article

\title{
Effect of herbal combination of triphala and Garcinia cambogia extracts on liver function test and kidney function test in high fat diet induced obesity in rats
}

\author{
Vijay Kumar A. N. ${ }^{1 *}$, Vijay Thawani ${ }^{2}$, Lal Hingorani ${ }^{3}$
}

\begin{abstract}
${ }^{1}$ Department of Pharmacology, DVVPF'S Medical College and Hospital, Ahmednagar,

Maharashtra, India

${ }^{2}$ Department of Pharmacology, People's College of Medical Sciences and Research Centre, Bhanpur, Bhopal, India ${ }^{3}$ Pharmanza Herbal Pvt. Ltd., Gujarat, India
\end{abstract}

Received: 10 October 2019

Revised: 15 November 2019

Accepted: 18 November 2019

*Correspondence to:

Dr. Vijay Kumar A. N., Email: vijaykumar.pharma @gmail.com m

Copyright: () the author(s), publisher and licensee Medip Academy. This is an openaccess article distributed under the terms of the Creative Commons Attribution NonCommercial License, which permits unrestricted noncommercial use, distribution, and reproduction in any medium, provided the original work is properly cited.

\begin{abstract}
Background: Obesity, a global epidemic, is a major risk factor for diabetes mellitus and cardio vascular diseases. Despite advances, the pharmacotherapy for obesity remains limited. Almost all medications for long term management of obesity have health issues. Due to the adverse drug reactions (ADRs) associated with many antiobesity medicines, the clinical trials are focussing on screening herbal medicines for use in the treatment of obesity, which have minimal ADRs.
\end{abstract}

Methods: Rats were divided into eight groups of six each. The rats were first made obese by feeding high fat diet (HFD) for three weeks. Then treatment with the herbal extracts was given simultaneously with the HFD to the experimental groups. Rats were fed HFD for six weeks along with herbal extracts and the effect on their liver function test and kidney function test were evaluated.

Results: The rats fed HFD and supplemented with herbal preparations of Triphala and G. cambogia for six weeks, showed significant improvement in liver function test and kidney function test related parameters as compared to the control group rats fed with HFD alone.

Conclusions: Triphala and G. cambogia can counter the effects of HFD intake and have the potential for use as anti-obesity agents with desirable liver function test and kidney function test related parameters modulating properties.

Keywords: Obesity, Triphala, Garcinia cambogia

\section{INTRODUCTION}

Obesity is a medical condition in which excess body fat is accumulated to the extent that it may harm health. ${ }^{1}$ Obesity is a risk factor for non-insulin-dependent diabetes mellitus (NIDDM), cardio vascular disease (CVD), osteoarthritis, cancer, reproductive and metabolic disorders. $^{2}$ It is also associated with disturbance in the hormonal milieu that can affect the reproductive system in women who present reproductive disorders when obese. $^{3,4}$ In humans, this relationship is poorly characterized, due to limited studies. ${ }^{5}$ Some energy balance genes are essential for normal regulation and mutation in a single gene can lead to obesity in lab animals. ${ }^{6}$ However, this does not explain obesity in the majority of the human population where no such genetic changes are seen. Concomitant diets are a major factor in the current obesogenic environment, and human obesity is diet-induced. ${ }^{6}$ Although genetic obesity models are useful in finding the role of endogenous neuropeptides in 
body weight control, the best parallels to human obesity are provided by the physiological model of diet-induced obesity. ${ }^{6,7}$

The causative factors of obesity are multiple and complex. The influence of the environment also exists, since the human genotype has not changed substantially in past 30 years. Thus, small changes in daily lifestyle, such as the use of machines for washing clothes and dishes and automobiles for transportation have a significant impact on the total daily energy spent. In addition to the total energy use due to low physical activity, environmental factors contribute to greater energy intake, through excess fat in the diet, consumption of high-calorie food, large-sized portions, frequency of food intake, lower cost and greater availability of food. ${ }^{8}$ The increased storage that creates obesity eventually leads to the release of excessive fatty acids from enhanced lipolysis, which is stimulated by the enhanced sympathetic state in obesity. ${ }^{9}$ The release of these excessive free fatty acids, lipids and their metabolites, creates oxidative stress to the endoplasmic reticulum and mitochondria. This affects adipose as well as non-adipose tissue. $^{10}$

The high prevalence of overweight and obesity, conjoint with their concomitant health risks, makes it particularly relevant worldwide public health challenge. Global projections estimate 1.12 billion individuals to be obese by the year 2030 and this rapid growth of obesity will occur in adults and children alike. ${ }^{11,12}$ Increase in weight and obesity are attributable to a global shift in diet towards increased intake of energy-dense foods and a trend towards less physical activity. Obesity is a major contributor to morbidity and mortality, surpassing drinking and smoking in negative effects on health. This will have negative effects on life expectancies of generations born after the rise of the obesity epidemic. ${ }^{13}$ The theories overlap. Firstly, obesity has been viewed as a disease of energy balance due to an excess intake and decreased expenditure. Attention has been focused on the mechanisms controlling feeding behaviour, food intake and adipose mass. ${ }^{15}$

Secondly, obesity is seen as a disorder of the adipocytes as it has a mechanism of fat storage and mobilization. With growing understanding, the traditional view of adipose tissue has switched from being a passive energy "reservoir" with insulator attributes to a complex, highly active and essential metabolic and endocrine organ, churning out an assortment of hormones and other signals regulating the body physiology (e.g., food intake, body weight and brain activity). ${ }^{16}$ It has been recognized as having an independent endocrine role that can result in an inflammatory response with increased risk of type 2 diabetes mellitus and cardio vascular disease (CVD), leading to increased morbidity and early mortality. ${ }^{17}$ Adipose tissue affects energy homeostasis and CV health by releasing adipokines that regulate energy expenditure, food intake, insulin sensitivity and inflammation. ${ }^{17}$ Thirdly, obesity is a neurobehavioral disorder with the control of appetite and food intake involved in obesity pathogenesis. ${ }^{14,17,18}$ Obesity is associated with insulin resistance, i.e., there is suppressed or delayed response to insulin. Hormones, cytokines and metabolic fuels from the adipocyte diminish insulin action. Large adipocytes in obese are resistant to insulin suppression of lipolysis, especially in visceral fat. These all result in increased levels of fatty acids and glycerol, which aggravate insulin resistance in skeletal muscles and liver. ${ }^{19}$ Obesity itself may also induce systemic oxidative stress and that increased oxidative stress in accumulated fat at least in part, the underlying cause of dysregulation of adipocytokines and development of metabolic syndrome.

Table 1: Mechanism of bioactive compounds of triphala.

\begin{tabular}{|c|c|c|}
\hline Herbal plant & Bioactive compounds & MOA \\
\hline $\begin{array}{l}\text { Terminalia } \\
\text { bellerica }\end{array}$ & $\begin{array}{l}\text { Tannins, quinines, phenols, coumarines, } \\
\text { flavanoids and phytosterols }\end{array}$ & Reduce lipids in serum. ${ }^{22}$ \\
\hline \multirow{2}{*}{$\begin{array}{l}\text { Emblica } \\
\text { officinalis }\end{array}$} & Flavonoids & $\begin{array}{l}\text { Improves lipid profiles by inhibiting synthesis of } \\
\text { cholesterol via decreasing hepatic 3-hydroxy-3-methyl } \\
\text { glutaryl-coenzyme A (HMG-CoA) reductase and also } \\
\text { enhances degradation of cholesterol. }{ }^{23}\end{array}$ \\
\hline & $\begin{array}{l}\text { Gallic acid, gallotanin, ellagic acid, } \\
\text { corilagin }\end{array}$ & $\begin{array}{l}\text { Antiobesity, anti-inflammatory, antidiabetic effects } \\
\text { through their antioxidant and free radical scavenging } \\
\text { properties. }\end{array}$ \\
\hline $\begin{array}{l}\text { Terminalia } \\
\text { chebula }\end{array}$ & $\begin{array}{l}\text { Gallic acid, methyl gallate, ethyl gallate, } \\
\text { chebulagic acid, tetra- } O \text {-galloyl- } \beta \text {-D- } \\
\text { glucose, ellagic acid, chebulinic acid and } \\
\text { penta- } O \text { galloyl- } \beta \text {-D-glucose, phenolic } \\
\text { compounds, punicalagin, Terflavin-A, } \\
\text { Terchebulin Girin. }\end{array}$ & Antiobesity, hypolipidemic effect. ${ }^{27,28}$ \\
\hline
\end{tabular}


Table 2: Mechanism of bioactive compounds of Garcinia cambogia.

\begin{tabular}{|c|c|c|}
\hline Herbal plant & Bioactive compounds & MOA \\
\hline \multirow{4}{*}{ Garcinia cambogia } & $\mathrm{HCA}$ & $\begin{array}{l}\text { Inhibits the enzyme ATP-citrate lyase, which is involved in } \\
\text { endogenous lipid biosynthesis. }\end{array}$ \\
\hline & $\mathrm{HCA}$ & $\begin{array}{l}\text { In addition, there is an increased production of hepatic glycogen } \\
\text { in the presence of HCA, which may activate glucoreceptors } \\
\text { leading to a sensation of fullness and reduced appetite. }\end{array}$ \\
\hline & HCA & $\begin{array}{l}\text { The increased bioavailability of serotonin is thought to be } \\
\text { related to appetite suppressing effects of supplemental HCA. }\end{array}$ \\
\hline & $\mathrm{HCA}$ & $\begin{array}{l}\text { Another possible MOA may be HCA's ability to down-regulate } \\
\text { Leptin, an amino acid hormone that induces obesity and body } \\
\text { weight. }\end{array}$ \\
\hline
\end{tabular}

Preventive or therapeutic strategies to control obesity should target the abnormalities associated with obesity. Pharmacological intervention includes sibutramine, orlistat, phentermine, diethylpropion, and fluoxetine or bupropion. Phentermine and diethylpropion have potential for abuse and are approved for short-term use. Approved medications for long term use in the treatment of obesity are sibutramine and orlistat, however, these should be used with caution in patients with history of CVD due to harmful ADRs associated. ${ }^{20}$ Due to the ADRs associated with many of the anti-obesity medicines, recent drug trials have focused on screening the herbal medicines to treat obesity with minimal ADRs. Anti-obesity foods may prevent the condition, possibly leading to the prevention of life style related diseases, if they are effective in reducing the visceral fat mass. This study was undertaken with an aim to evaluate the effect of herbal extracts of triphala, G. cambogia, and combination of triphala and G. cambogia extracts in an experimental model of high fat diet (HFD) induced obesity in albino Rats, in reducing the visceral fat deposition. $^{21}$

\section{Objectives}

The objectives of the present study were to study the effect of aqueous extract of triphala in HFD induced obesity model in rats, to study the effect of aqueous extract of $G$. cambogia in HFD induced obesity model in rats and to study the effect of combination of aqueous extracts of triphala and G. cambogia in HFD induced obesity model in rats.

\section{METHODS}

\section{Study design}

The prospective study was conducted on 48 male albino Wistar rats which weighed between 150-200 grams.

\section{Place of work done}

The study was conducted at Centre for Scientific Research and Development (CSRD), People's University, Bhopal.

\section{Herbal extracts for the study}

Standardized aqueous extracts of triphala was having tannins $45 \%$ and gallic acid by high performance liquid chromatography (HPLC) $7 \%$ and G. cambogia used contained $60 \%$ hydroxy citric acid by HPLC USP method. These extracts procured from Gujarat based certified company, M/s Pharmanza Herbal Pvt. Ltd. The doses were prepared freshly before experimentation.

\section{Materials used}

Triphala extract (Amla, Harad and Bahed), Garcinia cambogia extract and atorvastatin.

\section{Animal experiments}

All the animal experiments were performed in accordance with the protocol approved by the institutional animal ethics committee (IAEC) of People's College of Medical Sciences and Research Centre (PCMSRC), People's University, Bhopal, Madhya Pradesh, India.

\section{Procurement of rats and $\mathrm{HFD}$ diet}

The animals were purchased from National Institute of Nutrition, Hyderabad, Telangana India.

\section{Approval from IAEC}

The approval of IAEC, PCMSRC was obtained dated 30 November 2016.

\section{Housing and feeding conditions}

The rats were maintained in appropriate conditions as per the CPCSEA guidelines. The rats were maintained on standard pellet diet normal diet (ND) and HFD ad libitum and free access to water.

\section{Experimental diets}

Standard rat chow ND and HFD were purchased from National Institute of Nutrition Hyderabad, Telangana. 


\section{Description about grouping, dosing and feeding}

Animals were divided into 8 groups with each group consisting of six rats and the experimental period was 6 weeks.

- Group 1 was given normal diet and served as control.

- Group 2 was given HFD $45 \% \mathrm{kcal}$ fat throughout the study period of 42 days.

- Group 3 was given HFD for 21 days then from $22^{\text {nd }}$ day of the study till the end of the study atorvastatin and HFD. This group acted as positive control.

- Group 4 was given HFD for 21 days then from $22^{\text {nd }}$ day of the study till the end of the study triphala extract and HFD.

- Group 5 was given HFD for 21 days then from $22^{\text {nd }}$ day of the study till the end of the study G. cambogia extract and HFD.

- Group 6, 7, 8 were given HFD for 21 days then from $22^{\text {nd }}$ day of the study till the end of the studycombination of aqueous extract of G. cambogia and triphala at 500, 1000 and $2000 \mathrm{mg} / \mathrm{kg}$ respectively and HFD.

\section{Statistical analysis}

The data was expressed as mean $\pm \mathrm{SD}$ and analysed by using one-way ANOVA followed by post-hoc test. The values of $p<0.001$ and $\mathrm{p}<0.05$ were considered as statistically significant. Statistical software SPSS 25.0 version and statistical functions in MS-Excel 2010 were used.

\section{RESULTS}

\section{Liver function tests (LFT)}

ALT is a very good indicator enzyme to assess liver toxicity. We found the levels of ALT enzyme to be elevated after induction of obesity by HFD in 21 days, and its level significantly increased from a control value of $13.65 \pm 5.06$ to $17.55 \pm 5.35 \mathrm{U} / 1$. After 21 days of a combination of triphala and G. cambogia extract oral administration in male rats the value was $6.08 \pm 2.11 \mathrm{U} / \mathrm{l}$. With co-treatment of individual extracts of triphala and G. cambogia, the ALT levels were found to be $9.95 \pm 5.60$ $\mathrm{U} / \mathrm{l}, 6.8 \pm 4.40 * \mathrm{U} / \mathrm{l}$ which is also lower as like that of the combination extract-treated value $6.08 \pm 2.77 \quad \mathrm{U} / \mathrm{l}$ $(\mathrm{p}<0.05)$.

AST is a good indicator enzyme to assess liver toxicity. In our study, the levels of AST enzyme were found to be elevated after induction of obesity by HFD in 21 days, where its level increased from a control value of $21.93 \pm 6.98$ to $26.23 \pm 6.65$ U/l. After 21 days of a combination of triphala and G. cambogia extract oral administration in male rats the value was $8.11 \pm 4.27 \mathrm{U} / \mathrm{l}$. With co-treatment of individual extracts such as triphala extract and G. cambogia extract the ALT levels were found to be $20.9 \pm 9.13 \mathrm{U} /, 11.73 \pm 5.16 \mathrm{U} / 1$ which is decreased like with the combination extract-treated value $8.11 \pm 4.27 \mathrm{U} / \mathrm{l}$ but these values did not show any statistically significant difference $(\mathrm{p}<0.001, \mathrm{p}<0.05)$. ALP is an important diagnostic tool in hepatitis, biliary obstruction, hyperparathyroidism, etc. The value of alkaline phosphatise in this study was found to be elevated in 21days of HFD group in which the value increased from the control value of $18.50 \pm 2.58$ to $32.89 \pm 5.88 \mathrm{U} / 1$. On the other hand, co-treated rats with individual triphala and G. cambogia extracts showed a decreased level of ALP where the values were found to be $36.50 \pm 2.58 \mathrm{U} / 1 \quad(\mathrm{p}<0.05), 29.77 \pm 14.78 \mathrm{U} / 1 \quad(\mathrm{p}<0.05)$ respectively.

In the combination of triphala and G. cambogia treated group 107.31 $\pm 21.93 \mathrm{U} / \mathrm{l}(\mathrm{p}<0.001)$, all the values of ALP showed statistically significantly difference when the control group was compared to HFD, triphala, $G$. cambogia and the combination of triphala and $G$. cambogia. We investigated the effects of triphala extract, G. cambogia extract and combination of both extracts on protein concentration after the HFD induced obesity in male Wistar rats during 42 days of the experimental period. The data indicated that after induction of obesity by HFD in male Wistar rats, the level of total proteins decreased after 21 days, where the value was found to be $7.62 \pm 1.06 \mathrm{~g} / \mathrm{dl}(\mathrm{p}<0.05)$ which is lower than the control value of $8.58 \pm 0.9 \mathrm{~g} / \mathrm{dl} \quad(\mathrm{p}<0.05)$. With co-treatment of individual triphala extract and G. cambogia extract the total protein was found to be $8.45 \pm 0.91 \mathrm{~g} / \mathrm{dl}$ and $8.17 \pm 0.66 \mathrm{~g} / \mathrm{dl}$ respectively which is almost equal to control group values of $8.58 \pm 0.9 \mathrm{~g} / \mathrm{dl}$. With co-treatment of the combination of triphala and G. cambogia values two deferent doses were $9.08 \pm 0.57(\mathrm{p}<0.05), 9.66 \pm 0.60$ $\mathrm{g} / \mathrm{dl}(\mathrm{p}<0.05)$ respectively.

Table 3: Effect of drugs on ALT or SGPT.

\begin{tabular}{|c|c|c|c|c|c|c|c|c|}
\hline Week & Control & HFD & HFD+A & HFD+T & HFD+GC & $\begin{array}{l}\text { HFD+T+GC } \\
(500 \mathrm{mg} / \mathrm{kg})\end{array}$ & $\begin{array}{l}\text { HFD+T+GC } \\
(1000 \mathrm{mg} / \mathrm{kg})\end{array}$ & $\begin{array}{l}\text { HFD+T+GC } \\
(2000 \mathrm{mg} / \mathrm{kg})\end{array}$ \\
\hline 0 day & $\begin{array}{l}22.78 \pm \\
4.50\end{array}$ & $\begin{array}{l}13.65 \\
\pm 5.06\end{array}$ & $\begin{array}{l}6.56 \pm \\
2.72\end{array}$ & $\begin{array}{l}12.5 \pm \\
3.58\end{array}$ & $\begin{array}{l}8.9 \pm \\
4.38\end{array}$ & $\begin{array}{l}18.15 \pm \\
2.87\end{array}$ & $\begin{array}{l}6.03 \pm \\
3.36\end{array}$ & $\begin{array}{l}8.78 \pm \\
4.48\end{array}$ \\
\hline $\begin{array}{l}21^{\text {st }} \\
\text { day }\end{array}$ & $\begin{array}{l}20.23 \pm \\
6.53\end{array}$ & $\begin{array}{l}17.55 \\
\pm 5.35\end{array}$ & $\begin{array}{l}10.76 \pm \\
3.73\end{array}$ & $\begin{array}{l}15.11 \pm \\
3.20\end{array}$ & $\begin{array}{l}10.23 \pm \\
5.04\end{array}$ & $\begin{array}{l}20.86 \pm \\
3.38\end{array}$ & $\begin{array}{l}8.15 \pm \\
2.44\end{array}$ & $\begin{array}{l}12.98 \pm \\
2.66\end{array}$ \\
\hline $\begin{array}{l}42^{\text {nd }} \\
\text { day }\end{array}$ & $\begin{array}{l}16.21 \pm \\
6.76\end{array}$ & $\begin{array}{l}12.23 \\
\pm 7.02\end{array}$ & $\begin{array}{l}8.86 \pm \\
4.48\end{array}$ & $\begin{array}{l}9.95 \pm \\
5.60\end{array}$ & $\begin{array}{l}6.8 \pm \\
4.40\end{array}$ & $\begin{array}{l}14.65 \pm \\
6.13\end{array}$ & $\begin{array}{l}5.13 \pm \\
1.72 *\end{array}$ & $\begin{array}{l}6.08 \pm \\
2.77\end{array}$ \\
\hline
\end{tabular}

Values are mean \pm SEM; $n=6$ in each group. All means are statistically significantly different $(* *: p<0.001, *: p<0.05$, \#: $>0.05$ statistically insignificant); A: Atorvastatin; T: Triphala; GC: G. cambogia. 
Table 4: Effect of drugs on AST or SGOT.

\begin{tabular}{|lllllllll|} 
Week & Control & HFD & HFD+A & HFD+T & HFD+GC & $\begin{array}{l}\text { HFD+T+GC } \\
(\mathbf{5 0 0} \mathbf{~ m g / k g})\end{array}$ & $\begin{array}{l}\text { HFD+T+GC } \\
(\mathbf{1 0 0 0} \mathbf{~ m g} / \mathrm{kg})\end{array}$ & $\begin{array}{l}\text { HFD+T+GC } \\
(\mathbf{2 0 0 0} \mathbf{~ m g} / \mathbf{k g})\end{array}$ \\
\hline 0 day & $32.03 \pm$ & $21.93 \pm$ & $20.41 \pm$ & $25.45 \pm$ & $9.45 \pm$ & $11.81 \pm$ & $10.16 \pm$ & $13.96 \pm$ \\
& 4.43 & 6.98 & 6.84 & 6.09 & 3.72 & 2.68 & 5.95 & 4.08 \\
\hline $\mathbf{2 1}^{\text {st }}$ & $33.56 \pm$ & $26.23 \pm$ & $23.63 \pm$ & $28.96 \pm$ & $14.55 \pm$ & $16.55 \pm$ & $13.76 \pm$ & $11.28 \pm$ \\
day & 4.37 & 6.65 & 7.50 & 5.57 & 5.76 & 4.77 & 5.67 & 5.67 \\
\hline $\mathbf{4 2}^{\text {nd }}$ & $23.11 \pm$ & $17.15 \pm$ & $16.46 \pm$ & $20.9 \pm$ & $11.73 \pm$ & $12.03 \pm$ & $11.61 \pm$ & $8.11 \pm$ \\
day & 10.25 & 6.77 & 9.96 & 9.13 & 5.16 & 7.22 & 5.28 & 27 \\
\hline
\end{tabular}

Values are mean \pm SEM; $\mathrm{n}=6$ in each group. All means do not show any statistically significant difference $\left(* *: \mathrm{p}<0.001,{ }^{*}: \mathrm{p}<0.05,{ }^{*}\right.$ : p>0.05 statistically insignificant); A: Atorvastatin; T: Triphala; GC: G. cambogia.

Table 5: Effect of drugs on ALP.

\begin{tabular}{|lllllllll|} 
Week & Control & HFD & HFD+A & HFD+T & HFD+GC & $\begin{array}{l}\text { HFD+T+GC } \\
(\mathbf{5 0 0} \mathbf{~ m g / k g})\end{array}$ & $\begin{array}{l}\text { HFD+T+GC } \\
(\mathbf{1 0 0 0} \mathbf{~ m g} / \mathbf{k g})\end{array}$ & $\begin{array}{l}\text { HFD+T+GC } \\
(\mathbf{2 0 0 0} \mathbf{~ m g} / \mathrm{kg})\end{array}$ \\
\hline 0 day & $18.50 \pm$ & $23.05 \pm$ & $30.91 \pm$ & $40.63 \pm$ & $60.97 \pm$ & $116.65 \pm$ & $66.41 \pm$ & $116.1 \pm$ \\
\hline $\mathbf{2 1}^{\text {st }}$ & 2.58 & 3.25 & 6.10 & 5.83 & 8.20 & 5.13 & 6.52 & 6.26 \\
day $^{\text {nd }}$ & 34.85 & $32.89 \pm$ & $33.15 \pm$ & $31.80 \pm$ & $31.15 \pm$ & $166.36 \pm$ & $71.81 \pm$ & $121.32 \pm$ \\
\hline $\mathbf{4 2}^{\text {nd }}$ & $38.92 \pm$ & $29.77 \pm$ & $35.41 \pm$ & 4.88 & 15.55 & 13.42 & 8.58 & 7.10 \\
day & 26.57 & 6.86 & 3.54 & $2.58^{*}$ & $14.78^{*}$ & $148.75 \pm$ & $69.65 \pm$ & $107.31 \pm$ \\
\hline
\end{tabular}

Values are mean \pm SEM; $n=6$ in each group. All means are statistically significantly different $\left(* *: p<0.001, *: p<0.05\right.$, ${ }^{\#}: p>0.05$ statistically insignificant); A: Atorvastatin; T: Triphala; GC: G. cambogia.

Table 6: Effect of drugs on total protein.

\begin{tabular}{|lllllllll|} 
Week & Control & HFD & HFD+A & HFD+T & HFD+GC & $\begin{array}{l}\text { HFD+T+GC } \\
(\mathbf{5 0 0} \mathbf{~ m g / k g})\end{array}$ & $\begin{array}{l}\text { HFD+T+GC } \\
(\mathbf{1 0 0 0} \mathbf{~ m g / k g})\end{array}$ & $\begin{array}{c}\text { HFD+T+GC } \\
(\mathbf{2 0 0 0} \mathbf{~ m g / k g})\end{array}$ \\
\hline $\mathbf{0}$ day & $8.58 \pm$ & $7.06 \pm$ & $7.14 \pm$ & $7.09 \pm$ & $6.88 \pm$ & $6.66 \pm$ & $7.89 \pm$ & $7.06 \pm$ \\
\hline $\mathbf{2 1}^{\text {st }}$ & 0.9 & 1.42 & 1.38 & 1.64 & 0.86 & 1.25 & 1.49 & 1.31 \\
day $^{\text {nd }}$ & 0.86 & $7.62 \pm$ & $7.46 \pm$ & $8.14 \pm$ & $7.71 \pm$ & $7.56 \pm$ & $8.58 \pm$ & $8.47 \pm$ \\
\hline $\mathbf{4 2}^{\text {nd }}$ & $7.65 \pm$ & $7.88 \pm$ & 1.02 & 1.03 & 0.77 & 098 & 0.90 & 0.99 \\
day & 0.80 & 1.05 & 0.78 & $8.45 \pm$ & $8.17 \pm$ & $8.26 \pm$ & $9.08 \pm$ & $9.66 \pm$ \\
\hline
\end{tabular}

Values are mean \pm SEM; $n=6$ in each group. All means are statistically significantly different $\left(* *: p<0.001, *: p<0.05\right.$, ${ }^{\#}: p>0.05$ statistically insignificant); A: Atorvastatin; T: Triphala; GC: G. cambogia.

Table 7: Effect of drugs on albumin.

\begin{tabular}{|lllllllll|}
\hline Week & Control & HFD & HFD+A & HFD+T & HFD+GC & $\begin{array}{l}\text { HFD+T+GC } \\
(\mathbf{5 0 0} \mathbf{~ m g} / \mathbf{k g})\end{array}$ & $\begin{array}{l}\text { HFD+T+GC } \\
(\mathbf{1 0 0 0} \mathbf{~ m g} / \mathbf{k g})\end{array}$ & $\begin{array}{l}\text { HFD+T+GC } \\
(\mathbf{2 0 0 0} \mathbf{~ m g} / \mathbf{k g})\end{array}$ \\
\hline 0 Day & $4.62 \pm$ & $4.59 \pm$ & $5.23 \pm$ & $3.85 \pm$ & $3.87 \pm$ & $4.05 \pm$ & $4.52 \pm$ & $4.06 \pm$ \\
& 0.66 & 0.91 & 1.11 & 0.89 & 0.48 & 0.84 & 1.18 & 1.28 \\
\hline $\mathbf{2 1}^{\text {st }}$ & $4.52 \pm$ & $4.90 \pm$ & $5.78 \pm$ & $4.11 \pm$ & $4.74 \pm$ & $4.54 \pm$ & $5.15 \pm$ & $5.54 \pm$ \\
Day & 0.60 & $0.54 *$ & 0.98 & 0.96 & 0.56 & 1.38 & 0.96 & 0.88 \\
\hline $\mathbf{4 2}^{\text {nd }}$ & $4.26 \pm$ & $3.75 \pm$ & $4.9 \pm$ & $3.40 \pm$ & $3.95 \pm$ & $3.58 \pm$ & $3.89 \pm$ & $2.94 \pm$ \\
Day & 0.66 & 0.78 & 0.96 & 0.70 & 0.69 & 1.46 & 1.07 & $0.88^{* *}$ \\
\hline
\end{tabular}

Values are mean \pm SEM; $\mathrm{n}=6$ in each group. All means are statistically significantly different $\left(* *: \mathrm{p}<0.001, *: \mathrm{p}<0.05\right.$, ${ }^{\#}: \mathrm{p}>0.05$ statistically insignificant); A: Atorvastatin; T: Triphala; GC: G. cambogia.

We found that with a combination of triphala and $G$. cambogia treatment for 21 days, the total protein levels slightly increased as compared to the control group. We investigated the effects of triphala extract, G. cambogia extract and combination of both extracts on albumin concentration after the HFD induced obesity in male Wistar rats during 42 days of the experimental period. The data indicated that after induction of obesity by HFD in male Wistar rats, the level of albumin increased after 21 days, where the value was found to be $4.90 \pm 0.54 \mathrm{~g} / \mathrm{dl}$ which is higher than the control value of $4.62 \pm 0.66 \mathrm{~g} / \mathrm{dl}$ $(\mathrm{p}<0.05)$. With co-treatment of individual triphala extract and G. cambogia extract, the albumin value was found to be $3.40 \pm 0.70 \mathrm{~g} / \mathrm{dl}$ and $3.95 \pm 0.69 \mathrm{~g} / \mathrm{dl}$ respectively, which is lower as compared to combination-treated value $1.94 \pm 0.88 \mathrm{~g} / \mathrm{dl}(\mathrm{p}<0.001)$. 
Our data shows that the combination of triphala and $G$. cambogia was effective than the individual herbal treatment.

Higher levels of bilirubin indicate different types of liver problems. Occasionally, higher bilirubin levels may indicate an increased rate of destruction of red blood cells (hemolysis). In our study we investigated the effects of triphala extract, G. cambogia extract and combination of both extracts on bilirubin concentration after the HFD induced obesity in male Wistar rats during 42 days of the experimental period.

Table 8: Effect of drugs on bilirubin.

\begin{tabular}{|lllllllll|}
\hline Week & Control & HFD & HFD+A & HFD+T & HFD+GC & $\begin{array}{l}\text { HFD+T+GC } \\
(\mathbf{5 0 0} \mathbf{~ m g / k g})\end{array}$ & $\begin{array}{l}\text { HFD+T+GC } \\
(\mathbf{1 0 0 0} \mathbf{~ m g} / \mathrm{kg})\end{array}$ & $\begin{array}{l}\text { HFD+T+GC } \\
(\mathbf{2 0 0 0} \mathbf{~ m g} / \mathrm{kg})\end{array}$ \\
\hline 0 day & $210.5 \pm$ & 156.48 & $181.33 \pm$ & $158 \pm$ & $242.16 \pm$ & $253 \pm$ & $273.41 \pm$ & $276 \pm$ \\
& 48.06 & \pm 46.36 & 31.97 & 23.39 & 30.28 & 16.39 & 29.88 & 18.52 \\
\hline $\mathbf{2 1}^{\text {st }}$ & $200.62 \pm$ & 167.75 & $193.34 \pm$ & $167.61 \pm$ & $252.22 \pm$ & $277.27 \pm$ & $317.12 \pm$ & $311.02 \pm$ \\
day & 55.91 & \pm 42.93 & 32.82 & 27.19 & 34.57 & 22.05 & 42.72 & 44.28 \\
\hline $\mathbf{4 2}^{\text {nd }}$ & $206.72 \pm$ & 165.66 & $190.21 \pm$ & $158.83 \pm$ & $240.94 \pm$ & $263.88 \pm$ & $304.89 \pm$ & $251.16 \pm$ \\
day & 33.10 & \pm 41.75 & 31.08 & 25.40 & $29.47^{\#}$ & $37.60^{\#}$ & $42.55^{\#}$ & $9.10^{\#}$ \\
\hline
\end{tabular}

Values are mean \pm SEM; $n=6$ in each group. All means do not show any statistically significant difference $\left(* *: p<0.001, *: p<0.05\right.$, ${ }^{\#}$ : p>0.05 statistically insignificant); A: Atorvastatin; T: Triphala; GC: G. cambogia.

Table 9: Effect of drugs on creatinine.

\begin{tabular}{|lllllllll|} 
Week & Control & HFD & HFD+A & HFD+T & HFD+GC & $\begin{array}{l}\text { HFD+T+GC } \\
(\mathbf{5 0 0} \mathbf{~ m g / k g})\end{array}$ & $\begin{array}{l}\text { HFD+T+GC } \\
(\mathbf{1 0 0 0} \mathbf{~ m g / k g})\end{array}$ & $\begin{array}{l}\text { HFD+T+GC } \\
(\mathbf{2 0 0 0} \mathbf{~ m g} / \mathbf{k g})\end{array}$ \\
\hline 0 day & $2.72 \pm$ & $1.89 \pm$ & $2.76 \pm$ & $2.81 \pm$ & $2.41 \pm$ & $2.94 \pm$ & $2.58 \pm$ & $2.69 \pm$ \\
& 0.45 & 0.72 & 0.82 & 0.82 & 0.67 & 0.58 & 0.86 & 0.90 \\
$\mathbf{2 1}^{\text {st }}$ & $2.75 \pm$ & $3.03 \pm$ & $3.84 \pm$ & $3.80 \pm$ & $3.51 \pm$ & $3.59 \pm$ & $3.63 \pm$ & $4.07 \pm$ \\
day & 0.64 & $0.78^{*}$ & 0.51 & 0.73 & 0.53 & 0.45 & 0.88 & 0.94 \\
\hline $\mathbf{4 2}^{\text {nd }}$ & $2.2 \pm$ & $1.52 \pm$ & $2.09 \pm$ & $2.17 \pm$ & $1.69 \pm$ & $1.87 \pm$ & $1.92 \pm$ & $1.19 \pm$ \\
day & 1.10 & 0.87 & 1.27 & $1.09^{*}$ & $0.79^{\#}$ & $0.78^{\#}$ & $0.80^{\#}$ & $0.54^{*}$ \\
\hline
\end{tabular}

Values are mean \pm SEM; $n=6$ in each group. All means are statistically significantly different $\left(* *: p<0.001, *: p<0.05\right.$, ${ }^{\#}: p>0.05$ statistically insignificant); A: Atorvastatin; T: Triphala; GC: G. cambogia.

Table 10: Effect of drugs on blood urea.

\begin{tabular}{|lllllllll|} 
Week & Control & HFD & HFD+A & HFD+T & HFD+GC & $\begin{array}{l}\text { HFD+T+GC } \\
(\mathbf{5 0 0 ~} \mathbf{~ m g} / \mathbf{k g})\end{array}$ & $\begin{array}{l}\text { HFD+T+GC } \\
(\mathbf{1 0 0 0} \mathbf{~ m g} / \mathbf{k g})\end{array}$ & $\begin{array}{l}\text { HFD+T+GC } \\
(\mathbf{2 0 0 0} \mathbf{~ m g} / \mathrm{kg})\end{array}$ \\
\hline 0 day & $50.05 \pm$ & $44.23 \pm$ & $47.09 \pm$ & $45.03 \pm$ & $46.11 \pm$ & $52.97 \pm$ & $48.31 \pm$ & $52.76 \pm$ \\
& 8.94 & 5.14 & 7.64 & 8.37 & 7.58 & 7.36 & 7.83 & 6.44 \\
$\mathbf{2 1}^{\text {st }}$ & $50.60 \pm$ & $64.55+$ & $50.63 \pm$ & $44.64 \pm$ & $48.76 \pm$ & $58.17 \pm$ & $53.64 \pm$ & $63.97 \pm$ \\
day & 7.26 & $2.15 *$ & 8.24 & 8.32 & 7.70 & 8.51 & 9.54 & 7.76 \\
\hline $\mathbf{4 2}^{\text {nd }}$ & $48.31 \pm$ & $39.51 \pm$ & $44.26 \pm$ & $31.37+$ & $44.25 \pm$ & $51.43 \pm$ & $44.19 \pm$ & $34.90 \pm$ \\
day & 4.85 & 8.62 & 8.90 & $1.09 *$ & $8.31^{\#}$ & $10.88^{\#}$ & $9.28^{\#}$ & $1.94 *$ \\
\hline
\end{tabular}

Values are mean \pm SEM; $n=6$ in each group. All means are statistically significantly different $\left(* *: \mathrm{p}<0.001, *: \mathrm{p}<0.05,{ }^{\#}: \mathrm{p}>0.05\right.$ statistically insignificant); A: Atorvastatin; T: Triphala; GC: G. cambogia.

The data indicated that after induction of obesity, the level of bilirubin decreased after 21days, where it was found to be $167.75 \pm 42.93 \mathrm{mg} / \mathrm{dl}$ which is higher than the control value of $210.5 \pm 48.06 \mathrm{mg} / \mathrm{dl}$. With the cotreatment of individual standard herbal extract, triphala and G. cambogia extracts bilirubin value was found to be $158.83 \pm 25.40 \mathrm{mg} / \mathrm{dl}$ and $240.94 \pm 29.47 \mathrm{mg} / \mathrm{dl}$ respectively which are slightly decreased. Co-treatment of the combination of triphala and G. cambogia, bilirubin value was found to be $251.16 \pm 9.10 \mathrm{mg} / \mathrm{dl}$, which is further lower.

\section{Kidney function test (KFT)}

Nephrotoxicity is one of the most common kidney problems and occurs when the body is exposed to a drug or toxin that causes damage to the kidneys. Creatinine is an important diagnostic tool in kidney diseases. Any changes in levels of creatinine in the blood are related to excretion and therefore reflect kidney function.

In our study we investigated the effects of triphala extract, G. cambogia extract and combination of both extracts on creatinine concentration after the HFD 
induced obesity in male Wistar rats during 42 days of the experimental period. The data indicated that after induction of obesity by HFD in male Wistar rats, the level of creatinine got increased after 21days, where the value was found to be $3.84 \pm 0.51 \mathrm{mg} / \mathrm{dl}$ which is higher than the control value of $2.72 \pm 0.45 \mathrm{mg} / \mathrm{dl} \quad(\mathrm{p}<0.001)$. With co-treatment of individual, triphala extract and $G$. cambogia extract, the creatinine value was found to be $2.17 \pm 1.09 \mathrm{mg} / \mathrm{dl}$ and $1.69 \pm 0.79 \mathrm{mg} / \mathrm{dl}$ respectively which is slightly decreased. With co-treatment of the combination of triphala and G. cambogia the creatinine value was found to be $1.19 \pm 0.54 \mathrm{mg} / \mathrm{dl}$, which is further less as compared to individual treatment values $(\mathrm{p}<0.001)$.

Blood urea nitrogen is an important diagnostic tool for nephrotoxicity. In our study, the blood urea level was found to be elevated in HFD induced obesity in albino Wistar rats in 21 days, in which the value increased from the control value of $50.05 \pm 8.94$ to $64.55+2.15 \mathrm{mg} / \mathrm{dl}$. After the 42 days, the treated Triphala and G. cambogia groups showed a slightly decreased level of blood urea where the value was found to be, $44.26 \pm 8.90 \mathrm{mg} / \mathrm{dl}$, $31.37+1.09 \mathrm{mg} / \mathrm{dl}$ and $44.25 \pm 8.31 \mathrm{mg} / \mathrm{dl}$ respectively which is more or less equal to the control group $50.05 \pm 8.94 \mathrm{mg} / \mathrm{dl}(\mathrm{p}<0.05)$.

On the other hand, co-treatment with the combination of triphala and $G$. cambogia extracts showed further decreased level of blood urea level where the value was found to be $34.90 \pm 1.94 \mathrm{mg} / \mathrm{dl}(\mathrm{p}<0.05)$.

As mentioned above the determination of blood urea in rats treated with $2000 \mathrm{mg} / \mathrm{kg} /$ body weight with combination treatment showed a significant drop down towards the control value indicating protective action of combination treatment.

\section{DISCUSSION}

Our study assessed the preventive as well as the curative aspects of the herbal extracts together or individually in HFD induced rat model for obesity. The LFT and KFT related markers were assessed. Many research reports show that triphala and G. cambogia were effective against obesity but these results have never been investigated scientifically. Further, the effect of combination of triphala and G. cambogia has never been tested for obesity. As per Ayurvedic texts, triphala can dissolve accumulated fat within the body. It has been reported that treatment with triphala lead to reduced appetite and weight loss. ${ }^{31}$ Triphala and G. cambogia can reduce food consumption in humans and rodent models of obesity, possibly by diverting carbohydrates and fatty acids that would have become fat in the liver, into hepatic glycogen. ${ }^{32,33}$ This metabolic change may send signal to the brain resulting in a reduced appetite. The active component of G. cambogia is hydroxycitric acid (HCA), a compound that inhibits the enzyme ATP-citrate lyase, which is involved in endogenous lipid biosynthesis.
Additionally, there is an increased production of hepatic glycogen in the presence of HCA, which may activate glucoreceptors leading to a sensation of fullness and reduced appetite. ${ }^{28-30}$ Phytochemical analysis of triphala shows the presence of polyphenols, tannins, flavanoids and glycosides. ${ }^{34}$ Tannins with a gallate group have been reported to bring about various physiological functions such as anti-lipidemic action in rats with hypercholesterolemia. Many reports have suggested functional phenolic compounds are also responsible for lipid-lowering action, beside antidiabetic and hypotriglyceridemic effects. In our study, the herbal treatment was also found to statistically improve liver function as assessed by the activity of liver-specific enzymes ALT, AST, ALP, albumin and bilirubin decrease in plasma as compared with the HFD group. The herbal treatment also decreased kidney function related parameters such as creatinine and urea as compared with the HFD group.

\section{CONCLUSION}

The herbal treatment significantly improved the clinical parameters such as ALT, AST, ALP, Albumin and Bilirubin decreased in plasma as compared with the HFD group. The herbal treatment also decreased kidney function related parameters such as creatinine and urea as compared with the HFD group. We hereby report for the first time in-vivo antiobesogenic effects of combination of triphala and G. cambogia.

Funding: No funding sources Conflict of interest: None declared

Ethical approval: The study was approved by the Institutional Ethics Committee

\section{REFERENCES}

1. Chavarro JE, Toth TL, Wright DL, Meeker JD, Hauser R. Body mass index in relation to semen quality, sperm DNA integrity, and serum reproductive hormone levels among men attending an infertility clinic. Fertil Steril. 2010;93(7):2222-31.

2. Mayes JS, Watson GH. Direct effects of sex steroid hormones on adipose tissues and obesity. Obes Rev. 2004;5(4):197-216.

3. Pasquali R, Pelusi C, Genghini S, Cacciari M, Gambineri A. Obesity and reproductive disorders in women. Hum Reprod Update. 2003;9(4):359-72.

4. Robker RL. Evidence that obesity alters the quality of oocytes and embryos. Pathophysiology. 2008;5(2):115-21.

5. Hammoud AO, Wilde N, Gibson M, Parks A, Carrell DT, Meikle W. Male obesity and alteration in sperm parameters. Fertil Steril. 2008;90(6):2222-5.

6. Archer ZA, Mercer JG. Brain responses to o besogenic diets and diet induced obesity. Proc Nutr Soc. 2007;66(1):124-30.

7. Tan HM, Gundlach AL, Morris JM. Exaggerated feeding response to central galanin-like peptide 
administration in diet-induced obese rats. Neuropeptides. 2005;39(3):333-6.

8. Hill JO, Melanson EL. Overview of the determinants of overweight and obesity, current evidence and research issues. Med Sci Sports Exerc. 1999;31(11):515-21.

9. Palatty PL, Saldanha E. Pharmacotherapy for weight management. JAPI. 2012;60(3):34-45.

10. Megraj KVK, Balaraman R, Meenakshisundaram K. Biological activities of some Indian medicinal plants. J Advan Pharm Educ Res. 2011;1(1):12-44.

11. Knowler W, Pettitt D, Saad M, Bennett P. Diabetes mellitus in the Pima Indians: incidence, risk factors and pathogenesis. Diabetes Metab Rev. 1990;6(1):127.

12. Stunkard A, Foch T, Hrubec Z. A twin study of human obesity. JAMA. 1986;256(1):51-4.

13. Hebebrand J, Friedel S, Schäuble N, Geller F, Hinney A. Perspectives: molecular genetic research in human obesity. Obes Rev. 2003;4(3):139-46.

14. Walley A, Asher J, Froguel P. The genetic contribution to non-syndromic human obesity. Nat Rev Genet. 2009;10(7):431-42.

15. Smith J, Al-Amri M, Dorairaj P, Snideman A. The adipocytes life cycle hypothesis. Clin Sci. 2006;110(1):1-19.

16. Macia L, Viltart O, Verwaerde C, Delacre M, Delanoye A, Grangette C. Genes involved in obesity: adipocytes, brain and microflora. Genes Nutr. 2006;1(3-4):189-212.

17. Korner J, Woods S, Woodworth K. Regulation of energy homeostasis and health consequences in obesity. Am J Med. 2009;122(4-1):S12-8.

18. O'Rahilly S, Farooqi I. Human obesity: a heritable neurobehavioral disorder that is highly sensitive to environmental conditions. Diabetes. 2008;57(11):2905-10.

19. Boden G. Role of fatty acids in the pathogenesis of insulin resistance and NIDDM. Diabetes. 1997;46(1):3-10.

20. Furukawa $S$. Increased oxidative stress in obesity and its impact on metabolic syndrome. J Clin Invest. 2004;114(12):1752-61.

21. Mahan LK, Escott-Stump S. Krause's food, nutrition, and diet therapy. 12th ed. Philadelphia: WB Saunders. 2008. Available at: https://trove.nla.gov.au /work/6084784?selectedversion=NBD20212902. Accessed on 29/07/2019.

22. Chinetti G, Fruchart JC, Staels B. Peroxisome proliferator-activated receptors and inflammation: from basic science to clinical applications. Int J Obes Relat Metab Disord. 2003;27(3):S41-5.

23. Anindita D, Sikha B, Biswajit D. Pharmacological activities of Baheda (Terminalia bellerica): a review. J Pharmacog Phytochemistr. 2016;5(1):194-7.

24. Yokozawa T, Kim HY, Kim HJ, Okubo T, Chu DC, Juneja LR. Amla (Emblica Officinalis Gaertn.) prevents dyslipidaemia and oxidative stress in the ageing process. Br J Nutr. 2007;97(6):1187-95.
25. Kamali SH, Khalaj AR, Shirin HR, Esfehani MM, Kamalinejad M, Larijani B. A systematic review of the antioxidant, anti-diabetic, and anti-obesity effects and safety of triphala herbal formulation. J Med Plants Res. 2013;7(14):831-44.

26. Juang LJ, Sheu SJ, Lin TC. Determination of hydrolyzable tannins in the fruit of Terminalia chebula Retz. by high-performance liquid chromatography and capillary electrophoresis. J Sep Sci. 2004;27(9):718-24.

27. Chattopadhyay RR, Bhattacharyya SK. Plant review Terminalia chebula. Pharmacognos Rev. 2007;23:145-50.

28. Kirby J, Philip N, Howles Y. Hypolipidemic effect of triphala in experimentally induced hypercholesteremic rats. J Lipid Res. 2004;45(1):8998.

29. Ferrara L. The Garcinia cambogia in phytotreatment of obesity: activities of the hydroxycitric acid. Europ Scientific J. 2014;10(21):291-301.

30. Maruthappan VK, Sakthi S. Hypolipedimic activity A Haritaki in atherogenic diet induced hyperlypidemic rats. $\mathrm{J}$ Adv Pharm tech Res. 2010;1(2):229-35.

31. Sergio W. A natural food, the malabar tamarind, may be effective in the treatment of obesity. Med Hypotheses. 1988;27(1):39-40.

32. Lowenstein JM. Effect of (-)-hydroxycitrate on fatty acid synthesis by rat liver in vivo. J Biol Chem. 1971;246(3):629-32.

33. Ohia SE. Safety and mechanism of appetite suppression by a novel hydroxycitric acid extract (HCA-SX). Mol Cell Biochem. 2002;238(1-2):89103.

34. Dagogo JS. Human leptin regulation and promise in pharmacotherapy. Curr Drug Targets. 2001;2:18195.

35. Kizhakkeveettil A, Jayagopal PS, Rose KK. Hypercholesterolemia and Ayurvedic Medicine: A Case Report. Topics Integrat Health Care. 2011;2(2).

36. Murali YK, Anand P, Tandon V, Singh R, Chandra R, Murthy PS. Long-term effects of Terminalia chebula Retz. on hyperglycemia and associated hyperlipidemia, tissue glycogen content and in vitro release of insulin in streptozotocin induced diabetic rats. Exp Clin Endocrinol Diabetes. 2007;115(10):641-6.

37. Yokozawa T, Kim HY, Kim HJ, Okubo T, Chu DC, Juneja LR. Amla (Emblica officinalis Gaertn.) prevents dyslipidemia and oxidative stress in the ageing process. Br J Nutr. 2007;97(6):1187-95.

Cite this article as: Kumar VAN, Thawani V, Hingorani L. Effect of herbal combination of triphala and Garcinia cambogia extracts on liver function test and kidney function test in high fat diet induced obesity in rats. Int J Basic Clin Pharmacol 2019;8:2713-20. 